\title{
Incorporating Cultural Design Elements in Mobile Applications Creative Industries in Malaysia: A Conceptual Study
}

\author{
Muhammad Zulhilmi Samsuri, Shamsul Arrieya Ariffin*, Nur Saadah Fathil \\ Faculty of Art, Computing and Creative Industry, Sultan Idris Education University; mu.zulhilmi.samsuri@gmail.com \\ Faculty of Art, Computing and Creative Industry, Sultan Idris Education University; shamsul@fskik.upsi.edu.my \\ Faculty of Art, Computing and Creative Industry, Sultan Idris Education University; nursaadah@fskik.upsi.edu.my \\ * Correspondence author \\ To cite this article (APA): Samsuri, M. Z., Ariffin, S. A., \& Fathil, N. A. (2021). Incorporating cultural design elements in \\ mobile applications creative industries in Malaysia: A conceptual study. Journal of ICT in Education, 8(2), 110-117. \\ https://doi.org/10.37134/jictie.vol8.2.10.2021
}

To link to this article: https://doi.org/10.37134/jictie.vol8.2.10.2021

\begin{abstract}
This paper aims to propose a conceptual study by a researcher who developed mobile application guidelines containing cultural design elements. In the creative industries sector, mobile applications are the creative multimedia division for advancing technology, the industry revolution 4.0 (IR 4.0), in developing creative products. The creative industries benefit from mobile applications since it allows for the digital manufacturing of creative products that meet the IR 4.0 era. However, research on the use of cultural design elements in mobile applications is understudied. The scope of this study focused on the development of mobile applications in Malaysia's creative industry facing IR 4.0. According to preliminary findings, there is a lack of cultural design elements in the current mobile applications. Therefore, the researcher will further develop design guidelines for mobile applications for the creative industries in the IR 4.0 era that include cultural design elements.
\end{abstract}

Keywords: creative industries, IR 4.0, mobile applications, cultural design elements.

\section{INTRODUCTION}

Creative industries are an industrial sector that is involved in the production of cultural products that are commercialized directly to users or through intellectual property (Kementerian Penerangan, Komunikasi \& Kebudayaan, 2010; Taylor \& Smith, 2007). The advancement of the world with technology has also made the creative industry introduce digital media as a new platform for the digital creative industry (Geng \& Zhou, 2015; Kementerian Penerangan, Komunikasi \& Kebudayaan, 2010; Dewan Rakyat Malaysia, 2009). The development of technology these days, especially in Industrial Revolution 4.0 (IR.40), significantly impacts creative industry development and related fields (Gui et al., 2021). This development directly contributes considerably to the social, economic, cultural, and technological development of all corners of the world. 
The National Creative Industry Policy (Kementerian Penerangan, Komunikasi \& Kebudayaan, 2010) was formed in Malaysia to lay out the foundations for developing creative industries. The policy leads and drives all creative activities more productively and economically through the synergy of the public and private sectors. Therefore, Malaysia has the potential to generate a high-income economy while also strengthening the country's cultural identity. Likewise, creative multimedia is the platform for developing digital creative products with a local touch. However, in IR 4.0 era, the policy must be re-evaluated and modified to foster and empower the expansion of the multimedia creative economy. Aside from that, the usage of cultural elements (Ariffin, Yatim, \& Daud, 2019) in the creation of creative products should be considered in developing mobile applications (Ariffin, 2016a; Ariffin, 2016b).

This article aims to propose a preliminary conceptual analysis of cultural design elements to construct Industrial Revolution 4.0-compliant mobile applications for Malaysia's creative industries.

\section{BACKGROUND}

The National Creative Industry Policy was launched in 2010. The policy focused on three main scopes of the creative industries which are creative multimedia, cultural arts, and cultural heritage. The creative multimedia industry is mainly focused on industries that apply the latest technology in producing creative products such as films and TVs, advertisements, design arts, animations, and digital content (Kementerian Penerangan, Komunikasi \& Kebudayaan, 2010)

The evolution of current technology is in trend with current development. In this era, the current technological evolution is Industry Revolution 4.0 (IR 4.0). Industry Revolution 4.0 refers to a group of cutting-edge innovations that are supposed to change the industrial landscape drastically. Nowadays, the change towards the evolution of technology has affected many parties, including the creative sector. IR 4.0, first used in Germany, aims to increase the attractiveness of German manufacturing to the world (Acatech, 2013).

The researcher in this study focuses on the use of mobile applications technology in creative industries. These days, technological advancements are altering the human landscape. With the advancement of technology, cell phone usage has become incredibly popular. Malaysia, for example, had a demand for mobile phones that exceeded 550,000 units sold via the Shopee app (Berita Harian Online, 2021).

According to data from Buildfire (2021), 88\% of today's mobile phone usage is spent on applications. Statista (2021) reported, 204 billion apps were downloaded in 2019, representing a 6\% increase over the previous year.

The creative sector can use mobile applications as a tool to develop more creative digital products as 
the use of mobile applications continues to grow. South Korea, for example, leverages existing mobile applications technologies to promote their creative products while promoting their country's culture (Kim, 2013, 2012; Jin, 2006). Another example is Indonesia, which promotes traditional foods via smartphone applications based on the notion of Augmented Reality technology (Alfian, Suyoto \& Albertus, 2020). Among other uses of mobile applications in the creative industries sector today, are stated in Table 1:

Table 1: Mobile Applications Used in Creative Industries

\begin{tabular}{|c|c|c|c|c|}
\hline Source \& Year & Mobile Apps & Technology & Sector & Country \\
\hline Astro (2021) & Astro Go & Interactive Mode & Entertainment & Malaysia \\
\hline Digital (2021) & Tonton & Streaming Service & Local Content & Malaysia \\
\hline $\begin{array}{l}\text { Weking, Suyoto } \\
\text { \& Santoso } \\
(2020)\end{array}$ & $\begin{array}{l}\text { Traditional } \\
\text { Food }\end{array}$ & Augmented Reality & $\begin{array}{l}\text { Traditional } \\
\text { Indonesian } \\
\text { Food }\end{array}$ & Indonesia \\
\hline $\begin{array}{l}\text { Wahab, Setiawan } \\
\text { \& Wahdiniwaty } \\
\text { (2017) }\end{array}$ & $\begin{array}{l}\text { Bandung } \\
\text { Raya }\end{array}$ & $\begin{array}{l}\text { Location-Based Service } \\
\text { (LBS) and Global } \\
\text { Positioning System (GPS) }\end{array}$ & $\begin{array}{l}\text { Tourism and } \\
\text { Creative Industry }\end{array}$ & Indonesia \\
\hline $\begin{array}{l}\text { Korea Times } \\
(2018)\end{array}$ & YouTube & Broadcasting & Music Video & $\begin{array}{l}\text { South } \\
\text { Korea }\end{array}$ \\
\hline IOC (2021) & $\begin{array}{l}\text { The Olympic } \\
\text { Museum in } \\
\text { AR }\end{array}$ & Augmented Reality & $\begin{array}{l}\text { Exhibition on } \\
\text { Sports Manga. }\end{array}$ & Japan \\
\hline TikTok (2021) & TikTok & Video Feed & $\begin{array}{l}\text { Creative \& funny } \\
\text { Video }\end{array}$ & China \\
\hline Future (2021) & WeTV & Streaming Media & Dramas \& Shows & China \\
\hline FZE (2019) & Quran & Audio Playback & Religion & Dubai \\
\hline $\begin{array}{l}\text { IKEA Systems } \\
(2021)\end{array}$ & IKEA & Augmented Reality & $\begin{array}{l}\text { Home Furnishing } \\
\text { Products }\end{array}$ & Sweden \\
\hline $\begin{array}{l}\text { InstantEncore } \\
(2021)\end{array}$ & $\begin{array}{l}\text { Florida Grand } \\
\text { Opera }\end{array}$ & Recording & $\begin{array}{l}\text { Music } \\
\text { Entertainment }\end{array}$ & Miami \\
\hline Instagram (2021) & Instagram & $\begin{array}{ll}\text { Minimum } & \text { Viable } \\
\text { Product (MVP) }\end{array}$ & Social Media & California \\
\hline Google (2011) & $\begin{array}{l}\text { Google Arts } \\
\& \text { Culture }\end{array}$ & Virtual Reality & Cultural & California \\
\hline Netflix (2019) & Netflix & $\begin{array}{l}\text { Artificial Intelligence (AI) } \\
\text { and Machine Learning } \\
(\mathrm{ML})\end{array}$ & $\begin{array}{l}\text { Digital } \\
\text { Entertainment }\end{array}$ & California \\
\hline Facebook (2021) & Facebook & $\begin{array}{l}\text { Machine Learning (ML), } \\
\text { Smart Displays \& Virtual } \\
\text { Reality }\end{array}$ & Community & The U.S. \\
\hline$\overline{\mathrm{BBC}}(2021)$ & $\begin{array}{l}\text { BBC Sounds: } \\
\text { Radio \& } \\
\text { Podcasts }\end{array}$ & $\begin{array}{l}\text { Cookies: Measure } \\
\text { Audience Behaviour }\end{array}$ & Music and Audio & The U.K. \\
\hline
\end{tabular}


In the table above, the results of the study indicate that the users of these mobile applications are worldwide in the creative industries. TikTok has become the largest revenue-earning non-game app on the App Store by 2020 (AboveAvalon, 2021). Hence a study to investigate the mobile applications setting (Ariffin, 2018; Ariffin \& Dyson, 2015; Ariffin, 2014), for creative industries for IR 4.0 is significant for this research in Malaysia.

\section{CHALLENGES}

In general, to obtain good quality of mobile applications as a digital media platform, it is required to build mobile applications led by design principles elements. However, a review of studies on current design principles revealed that research on the necessity for cultural design elements in mobile applications for the creative industries is still limited. Culture is such an essential and core notion in the creative sector because cultural design elements are required in the development of mobile applications used in the creative industries (UNESCO, 2012; Kementerian Penerangan, Komunikasi \& Kebudayaan, 2010). 2010). Furthermore, cultural components are significant since they reflect national identity, and customers prefer to access local cultural mobile applications (Kementerian Penerangan, Komunikasi \& Kebudayaan, 2010, 2010; Taylor \& Smith, 2007). This research examines five current design principles: 1. CADG (Ariffin, 2014); 2. Don Norman (Norman, 1988); 3. ISO 9241-11: 2018 (ISO, 2018); 4. 10 general principles of Jakob Nielsen (Nielsen, 1994); 5. Shneiderman's eight golden rules (Shneiderman, 1998). A comparison of each design principle is shown in table 2.

Table 2: Comparison of Design Principles

\begin{tabular}{|c|c|c|c|c|c|}
\hline ELEMENT & $\begin{array}{c}\text { CADG } \\
\text { (Ariffin, } \\
2014)\end{array}$ & $\begin{array}{c}\text { Don } \\
\text { Norman } \\
\text { (Norman, } \\
1988) \\
\end{array}$ & $\begin{array}{c}\text { ISO 9241- } \\
\mathbf{1 1} \\
\mathbf{2 0 1 8} \\
\text { (ISO, 2018) } \\
\end{array}$ & $\begin{array}{c}\text { Jakob } \\
\text { Nielsen } \\
\text { (Nielsen, } \\
1994) \\
\end{array}$ & $\begin{array}{c}\text { Shneiderman } \\
\text { (Shneiderman, } \\
1985)\end{array}$ \\
\hline Accessibility & $\checkmark$ & & & & \\
\hline Affordance & & $\checkmark$ & & $\checkmark$ & \\
\hline Consistency & $\checkmark$ & $\checkmark$ & & $\checkmark$ & $\checkmark$ \\
\hline Constraints & $\checkmark$ & $\checkmark$ & & $\checkmark$ & \\
\hline Effectiveness & & & $\checkmark$ & & \\
\hline Efficiency & $\checkmark$ & & $\checkmark$ & $\checkmark$ & \\
\hline Error Handling & & & & $\checkmark$ & $\checkmark$ \\
\hline Error Prevention & $\checkmark$ & & & $\checkmark$ & \\
\hline Feedback & & $\checkmark$ & & & $\checkmark$ \\
\hline Local Culture & $\checkmark$ & & & & \\
\hline Mapping & $\checkmark$ & $\checkmark$ & & $\checkmark$ & $\checkmark$ \\
\hline $\begin{array}{l}\text { Match Between System and } \\
\text { The Real World }\end{array}$ & & & & $\checkmark$ & \\
\hline $\begin{array}{l}\text { Permit Easy Reversal of } \\
\text { Actions }\end{array}$ & & & & & $\checkmark$ \\
\hline
\end{tabular}




\begin{tabular}{llll}
\hline Satisfaction & $\checkmark$ & & \\
\hline Shortcuts & & & $\checkmark$ \\
\hline User Control and Freedom & & $\checkmark$ & $\checkmark$ \\
\hline Visibility & $\checkmark$ & $\checkmark$ & $\checkmark$ \\
\hline
\end{tabular}

The table of comparison of design principles shows that design elements with cultural concepts are still limited. This is because the design principles that exist today are generic in use, and do not focus on the use of a particular industry such as the creative industry.

\section{SOLUTIONS}

This study proposes a modified Design and Development Research (DDR) approach (Siraj et al., 2018), which will go through 3 phases. The first phase of the study was the needs analysis phase, which used the content analysis methods to identify the needed elements in developing design guidelines. The second phase is the design and development phase; the initial instrument will be developed based on the findings of the first phase and the Fuzzy Delphi method to obtain the expert's agreement on the elements used in the instrument development. Finally, the evaluation phase will be based on the descriptive statistics method to rearrange each element according to the findings from the second phase based on its ranking values. The diagram of the proposed conceptual framework in this study is in Appendix 1.

\section{RECOMMENDATION}

This article proposed a conceptual framework. The research indicated the need to develop Culturally Appropriate Design Guidelines (CADG) for mobile applications for the creative industries in the IR 4.0 era. This is on par with the need to embed cultural design elements in constructing mobile applications for the creative industries, particularly for the users. After all, there is limited literature supporting cultural design guidelines (Ariffin, 2014) in the previous studies. Therefore, the researcher will conduct studies related to developing Culturally Appropriate Design Guidelines (CADG) for mobile applications used in the creative industries in favour of the IR 4.0 era.

Three objectives are to be executed in the upcoming research to achieve the main objective that is to develop guidelines with the cultural design elements for mobile applications. Firstly, it is to identify the cultural design elements needed in the design guidelines of mobile applications for creative industries in favour of IR 4.0. Secondly, it is to develop the design guidelines that will be used in mobile applications based on the Fuzzy Delphi Method (FDM). Thirdly, it is to rank the order of design elements based on their importance.

\section{FUTURE RESEARCH DIRECTIONS}

In the next phase, the researcher will conduct content analysis to construct the CADG design principles for the development of mobile application design. This is to discuss the elements needed 
in the guidelines to be developed. Additionally, the study will also seek the contribution of experts' verification in determining the suitability of each element used in the guidelines (Siraj et al., 2018).

\section{CONCLUSION}

To conclude, the advancement of technology has brought a meaningful change to the creative industries in the era of IR 4.0, particularly for mobile applications. For example, the utilization of mobile applications in digital creativity has become more advanced. Yet, there are limited researches conducted about the incorporation of cultural design elements in mobile application advancement. To resolve this issue, the study aims to develop culturally appropriate design guidelines (CADG) for mobile applications used in the creative industries in favour of IR 4.0.

\section{ACKNOWLEDGMENT}

This work was supported by the Ministry of Higher Education (Malaysia) under the Grant Research Consortium for Creative Industry \& Culture (CICC) 2021-0042-106-10.

\section{REFERENCES}

Acatech, (2013). Zukunftsprojekt Industrie 4.0. Zeitschrift Für Wirtschaftlichen Fabrikbetrieb, 108(5), 275. https://doi.org/10.3139/104.013051

Ariffin, S. A., Yatim, M. H. M., \& Daud, F. (2019). Identification of usability impact of mobile learning STEM in a local university context. In Proceedings of the 5th International ACM In-Cooperation HCI and UX Conference (pp. 106 $115)$.

Ariffin, S. A. (2018). Towards a smart educational environment framework for learning in a Malaysian context. In Proceedings of the $4^{\text {th }}$ International Conference on Human-Computer Interaction and User Experience in Indonesia, CHIuXiD'18 (pp. 74-81).

Ariffin, S. A. (2016). Investigating the Daily Use of Mobile Phones as Tools to Enhance mLearning for Local Cultural Subjects in the Context of Malaysian Universities. In Mobile and Blended Learning Innovations for Improved Learning Outcomes (pp. 143-158). IGI Global. https://doi.org/ 10.4018/978-1-5225-0359-0.ch008

Ariffin, S. A. (2016). Academics' Perspectives on the Challenges and Opportunities for Student-Generated Mobile Content in Malaysia. International Journal of Mobile and Blended Learning (IJMBL), 8(3), 49-64. https://doi.org/10.4018/IJMBL.2016070104

Ariffin, S. A., \& Dyson, L. E. (2015, August). Culturally appropriate design of mobile learning applications in the Malaysian context. In International conference on cross-cultural design (pp. 3-14). Springer, Cham. https://doi.org/10.1007/978-3-319-20934-0_1

Bernama. (2019, March 13). Seni dan budaya cerminan ketamadunan negara - Dr. Mahathir | JKKN. Utusan Online. http://www.jkkn.gov.my/ms/seni-dan-budaya cerminan-ketamadunan negara-dr-mahathir

Berita Harian. (2021, January 26). Permintaan luar biasa gajet di Shopee semasa PKP 2.0. https://www.bharian.com.my/bisnes/teknologi/2021/01/780070/permintaan-luar-biasa-gajet di-shopee-semasa-pkp

Buildfire. (2021). Mobile App Download and Usage Statistics 2021. https://buildfire.com/app-statistics

Dewan Rakyat Malaysia. (2009). Perbahasan rang undang-undang perbekalan. Penyata Rasmi Dewan Rakyat. 3(09), 1932 
2314 Parlimen Keempat belas Penggal Kedua.

Fedorychak, V. (2021). Mobile App Industry Statistics (2021): Downloads, Usage, and Other Facts You Should Know. Living. $\quad$ https://lvivity.com/mobile-app-industry-statistics-2021

Geng, W., \& Zhou, H. X. (2015). Development of Digital Media and Creative Industries under the New Economic Era. In Advanced Materials Research (Vol. 1079, pp. 1299-1301). Trans Tech Publications Ltd. https://doi.org/10.4028/www.scientific.net/AMR.1079-1080.1299

Gui, A., Fernando, Y., Shaharudin, M. S., Mokhtar, M., \& Karmawan, I. G. M. (2021). Drivers of Cloud Computing Adoption in Small Medium Enterprises of Indonesia Creative Industry. JOIV: International Journal on Informatics Visualization, 5(1), 69-75. http://dx.doi.org/10.30630/joiv.5.1.461

Google. (2011). Google Arts \& Culture. https://artsandculture.google.com/.

ISO.(2018). Ergonomics of human-system interaction - Part 11: Usability: Definitions and concepts. ISO 924111:2018(en). https://www.iso.org/obp/ui/\#iso:std:iso:9241:-11:ed-2:v1:en.

Jin, D. Y. (2006). Cultural politics in Korea's contemporary films under neoliberal globalization. Media, Culture \& Society, 28(1), 5-23. https://doi.org/10.1177/0163443706059274

Kementerian Penerangan, Komunikasi \& Kebudayaan. (2010). Dasar Industri Kreatif Negara. https://www.kkmm.gov.my/pdf/Dasar/dikn.pdf

Kim M (2013) Budgets on the support program on Korean indie music and musicians. Master's Thesis, Sangmyung University. Seoul National University.

Nielsen, J. (1994). Enhancing the explanatory power of usability heuristics. In Proceedings of the SIGCHI conference on Human Factors in Computing Systems (pp. 152-158).

Norman, D. (1988). The Psychology of Everyday Things (1st ed.). Basic Books.

Saedah, S., Muhammad Ridhuan, T. L. A., \& Rozaini, M. R. (2020). Pendekatan Penyelidikan Rekabentuk dan Pembangunan (PRP): Aplikasi kepada Penyelidikan Pendidikan. Tanjong Malim, Perak: Penerbit UPSI.

Shneiderman, B. (1998). Designing the User Interface: Strategies for Effective Human-Computer Interaction (3rd edition), Addison-Wesley, Reading, MA.

Sima, V., Gheorghe, I. G., Subić, J., \& Nancu, D. (2020). Influences of the Industry 4.0 Revolution on the Human Capital Development and Consumer Behavior: A Systematic Review. Sustainability, 12(10), 4035. https://doi.org/10.3390/su12104035

Statista. (2021). The Annual Number of Global Mobile App Downloads 2016-2020. https://www.statista.com/statistics/271644/worldwide free-and-paid-mobile-app-store downloads/

Taylor, I., \& Smith, K. (2007). United Nations Conference on Trade and Development (UNCTAD). Routledge.

Wahab, D. A., Setiawan, E. B., \& Wahdiniwaty, R. (2017). Information distribution service of tourism and creative industry using mobile application technology. International Journal of New Media Technology, 4(2), 120-125. https://doi.org/10.31937/ijnmt.v4i2.653

Weking, A. N., Suyoto, S., \& Santoso, A. J. (2020). A development of augmented reality mobile application to promote the traditional Indonesian food. International Journal of Interactive Mobile Technologies, 14(09), 248 https://doi.org/10.3991/ijim.v14i09.11179 


\section{APPENDIX 1}

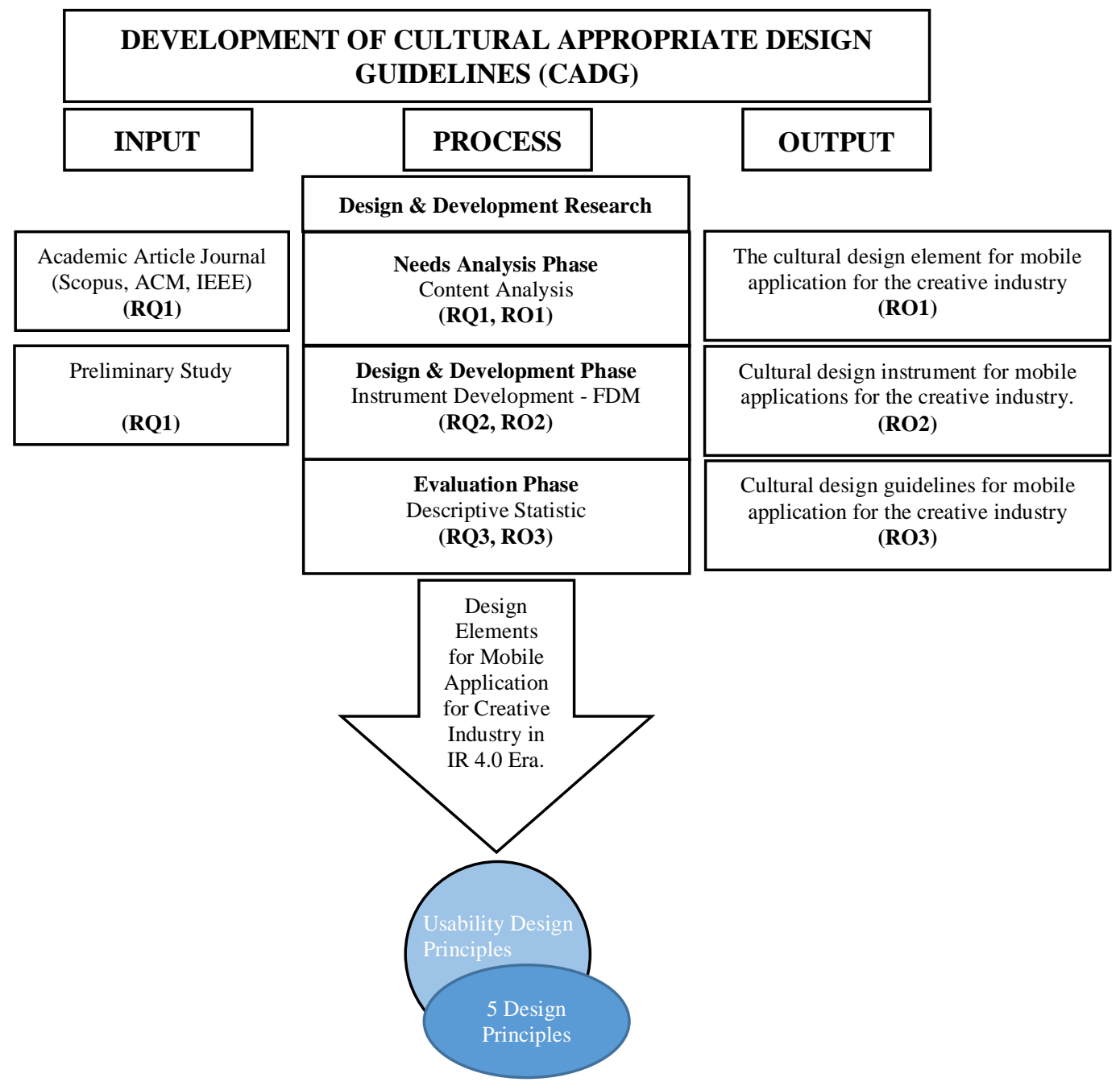

- $\quad$ Design Guidelines for Mobile Application for Creative Industry in favour of IR 4.0 Era.

- The cultural design elements for mobile applications for the creative industry in IR 4.0 (RQ1, RO1).

- $\quad$ Design guidelines for mobile applications for the creative industry in IR 4.0 using Fuzzy Delphi (RQ2, RO2).

- Design guidelines with the order of important elements (RQ3, RO3).

Notes:

5 Design Principles - CADG, Don Norman, ISO 9241-11 2018, Jakob Nielsen, Shneiderman. $\mathrm{RQ}$ - Research question, $\mathrm{RO}$ - Research objective 